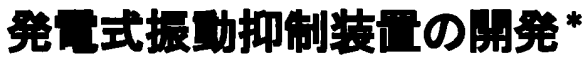

藤井 遊介 ${ }^{* 1}$, 和田 拓也 ${ }^{* 2}$, 松岡 太一 $^{* 3}$

\section{Dynamic Absorber that Generates Electric Power}

\author{
Yusuke FUJII" ${ }^{* 1}$, Takuya WADA and Taichi MATSUOKA \\ ${ }^{* 1}$ Graduate School of Science and Technology, Meiji University \\ 1-1-1 Higashimita, Tama-ku, Kawasaki, Kanagawa, 214-8571 Japan
}

In this paper the authors propose a dynamic absorber for a pole structure, as like a traffic signal pole on an express highway, in order to not only dissipate vibration energy, and also obtain an electrical energy. To investigate dynamic property, a test dynamic absorber that consist of rare-earth magnet, solenoid coil and spring was manufactured. An electric power and a damping force are measured by a shaking table. Also magnetic flux density around the solenoid coil with the magnets is analyzed by using FEM, and output voltage is calculated. Vibration tests of the test absorber are carried out and the experimental results are compared with the calculated results. The dynamic absorber is installed on a $1 / 3$ scales pole structure model of, and investigate frequency responses by the test dynamic absorber.

Key Words : Dynamic Absorber, Damping, Vibration Control, Electromagnetic Induction, Electrical Power, Pole Structure

\section{1.}

高速道路の標識柱は，走行車や風の振動により標識柱の疲労破損が起こる現象が問題視されている．制振方法 として固定面を用いた制振方法や支持的構造物による制振，また任意に取り付ける制振方法がある. 固定面を用 いた方法は制振力を簡単に発生させることはできるが固定面とする対象が少ないという点がある. また支持構造 物を用いた制振方法は支持的構造物を必要とするため高速道路という限られたスペースでは設置が困難であり， また特別な補強等をするとコスト面に問題が出てしまう．それに対して任意の場所に設置できる制振方法は現行 物のままで制振を試みるのが可能で，簡易的でローコストであるという利点がある.

取り付ける制振装置の中で動吸振器が取り上げられる. 動吸振器とは, 加わる振動と逆の動きをさせることで 振動エネルギーを吸収する構造をした装置である. 動吸振器のメリットとして，比較的構造が簡易的で製造する のにローコストであり取り付けが容易だが, その反面動吸振器のパラメーターの調整が困難といったデメリット がある. 建築分野では地震動に対するエネルギー吸収を目的とした能動型動吸振器や(1), 機械分野では形状記憶 合金を用いた動吸振器に関する研究(2)などがされている.

また，振動エネルギーを電気エネルギーに変換する研究も近年関心を寄せている．車のサスペンション ${ }^{(3)}$ 塔上構造物の風による振動 ${ }^{(4)}$, 歩行発電(5) など様々な研究が進められている. 振動エネルギーを電気エネルギー に変換し, 外部に供給することで再生エネルギーとして使用できる. このコンセプトをもとに, 動吸振器に非接 触でダンピングを与えることができる磁気ダンパの構造を利用して，ローレンツカによる減衰だけではなく、コ イルを利用した電磁誘導により誘導起電力を生じさせてエネルギーを消散させ,かつ発電できる装置を考案した.

そこで, 本研究では, 高速道路の標識柱の振動を制振しつつ, かつ振動エネルギーを熱エネルギーとして消散

*原稿受付 2012 年 7 月 17 日

*1 学生員, 明治大学大学院理工学研究科 (下214-8571 神奈川県川崎市多摩区三田 1-1-1)

2 明治大学大学院理工学研究科

*3 正員, 明治大学理工学部

E-mail: matsuoka@meiji.ac.jp 
するのではなく電気エネルギーに変換し，照明灯などに電力を供給することが可能な発電式振動抑制装置の開発 を目的とする. 開発した発電式振動抑制装置の性能を有限要素法プログラム(ANSYS)を用いて磁束密度変化を調 べ非線形の関数と同定を行い発電と減衰の理論式を求め, 強制振動による実験結果と比較検討した. また $1 / 3$ ス ケールの標識柱モデルに発電式振動抑制装置を取り付けて，周波数応答の実験を行い，本装置の制振性能と発電 性能の有用性について確認を行った.

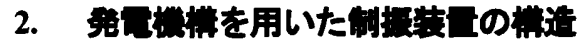

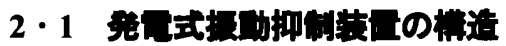

本装置の構造を図 1 に，諸元を表 1 に示す，本装置はネオジム磁石(1), 短形状のコイル(2), 引張ばね(4), 質量 体(5)によって構成されている. コイルと質量体が丸棒の先端にそれぞれ固定されており，外部の振動によってば ねを取り付けられた質量体が副振動系となる.コイルは単相で綎 $55 \mathrm{~mm}$, 横 $98 \mathrm{~mm}$, 高さ $20 \mathrm{~mm}$ となっており, コイルの中は縦 $30 \mathrm{~mm}$, 横 $70 \mathrm{~mm}$ の空洞となっている. コイルが振動する際にネオジム磁石とコイルが接触を起 こさないようにリニアブッシュ(3)を装置の上下面に設置している. コイルの線形は $0.5 \mathrm{~mm}$ でコイルの長さ $L$ は $103.5 \mathrm{~m}$ の銅線である. ネオジム磁石は縦 $15 \mathrm{~mm}$, 横 $10 \mathrm{~mm}$, 高さ $5 \mathrm{~mm}$ である. この磁石は極が同じ方向に向く ように 4 つ横並びで, 装置の側面板の内側に取り付けられている. 磁石同士の反発による磁石のずれを防ぐため に, 磁石を取り付ける側面板には $1.5 \mathrm{~mm}$ の溝を有し, 磁石をはめ込んである. 磁石の極は互いに極が SN, NS となるように配置した. 図の垂直方向の磁石間距離 $H$ は $52 \mathrm{~mm}$ である. またコイルの移動方向に対して垂直な 方向の磁石間距離は $21 \mathrm{~mm}$ となっている.

本装置は磁石から流れる磁束をコイルが横切って起こる電磁誘導によって発電される. そのため電磁誘導の際 には，コイルの進行方向とは反対にローレンツカが作用して減衰力が生じる仕組みである. コイルで発生した電 圧は電線を介し，外部に電力を供給できるようになっている.

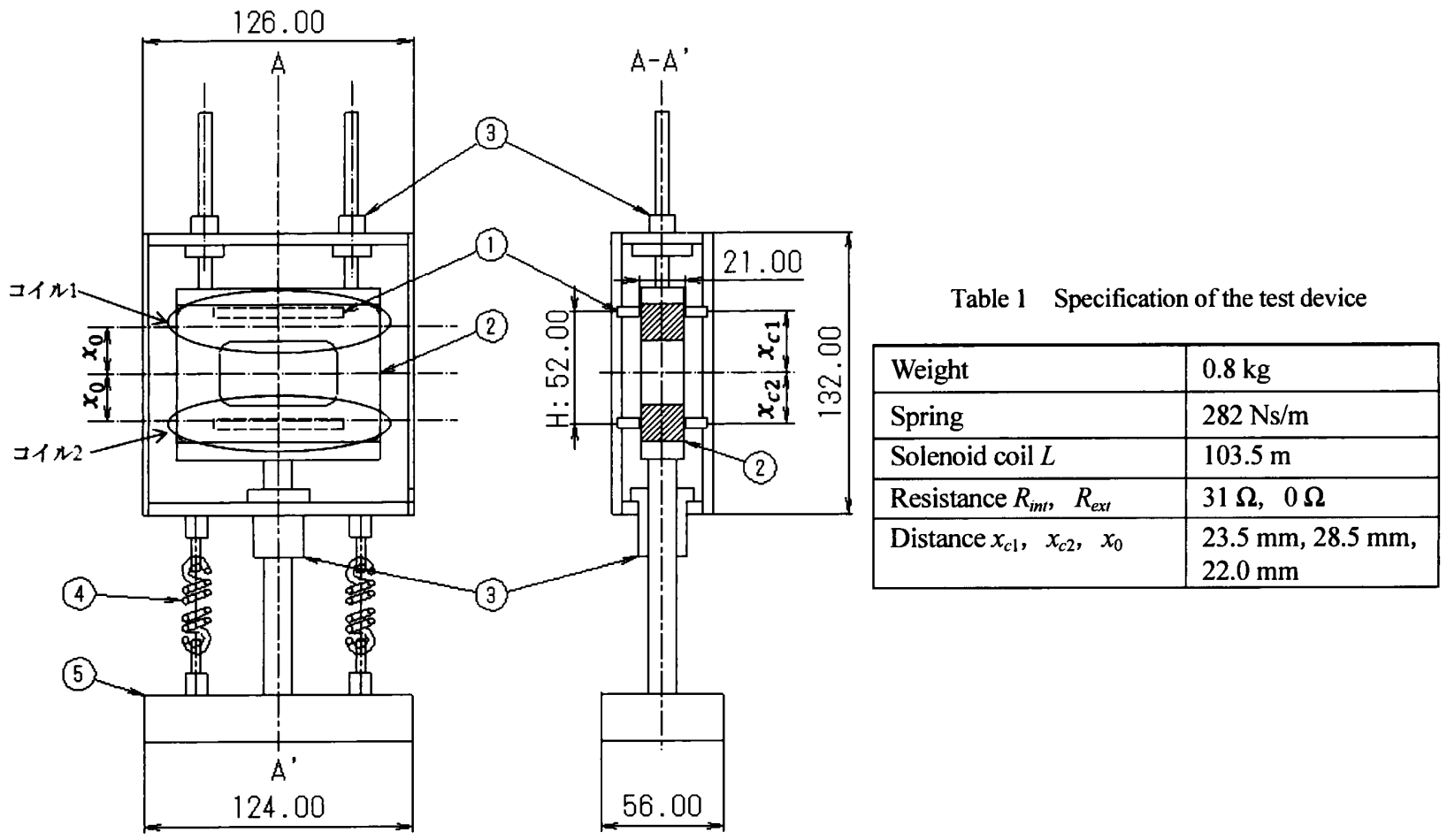

1. Rare-earth magnet 2. Solenoid coil

3. Linear bush 4. Spring

5. Weight

Fig. 1 Design diagram of the test device 


\section{$2 \cdot 2$ 碚束密度交化}

試作した装置内の磁束密度変化を有限要素法プログラム(ANSYS)によって調查した. 有限要素法に用いたモデ ル図を図 2 に示す. モデルは希土類磁石と鉄製の側面板と空気，無限境界で構成されている. 装置内の磁束密度 線図を図 3 に示す. 装置内の磁石の配置は前節や図 3 に示してすように $\mathrm{S}$ 極と $\mathrm{N}$ 極が交互になるように配置して いるので磁束の方向は上と下で逆向きである. ここで図 2 のモデルの中心 $B B^{\prime}$ の磁束密度変化を図 4 に示す. 装 置の中心の磁束密度の最大值は $118 \mathrm{mT}$ として得られた．また，実際に装置の磁束密度のピーク值をガウスメー タにより測定したところ, 装置の中心の磁束密度は $104 \mathrm{mT}$ と測定された. これは有限要素法を二次元平面で行 ったため奥行方向の磁束密度が低くなっていることが考えられる. 装置の中心の磁束密度を求めるのはコイルが 横切る磁束密度の最大値を決めるためである.

\section{$2 \cdot 3$ 筃てと注裳力の理式}

ファラデーの法則より電圧の式は以下のようにして表される. 本節では有限要素法によって示された磁束密度 変化を距離 $x$ の関数として同定する.

$$
V(t)=B(x) v(t) L
$$

ここでB(t)は磁束密度変化，Lはコイルの長さである．コイルの変位を, $x(t)$ 速度を $v(t)$ とすると

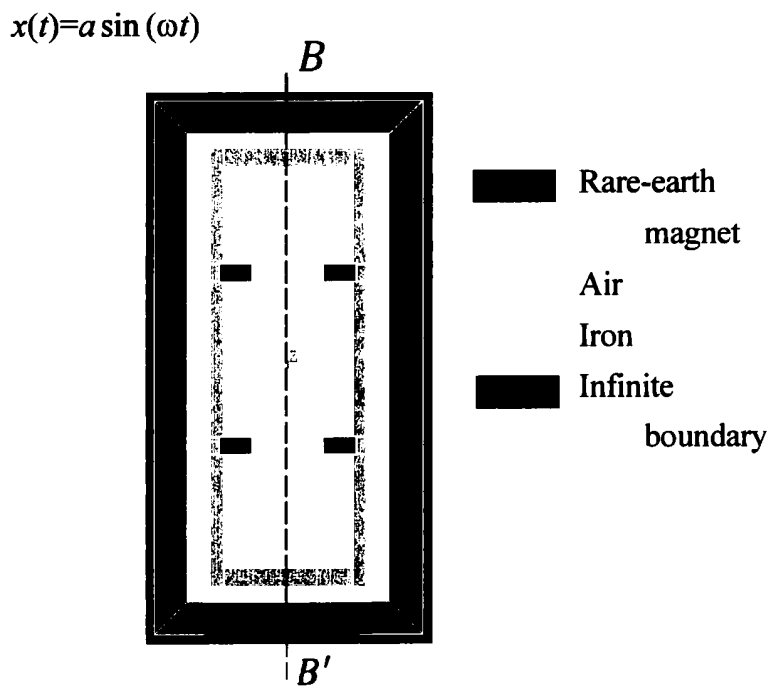

Fig. 2 Analytical model

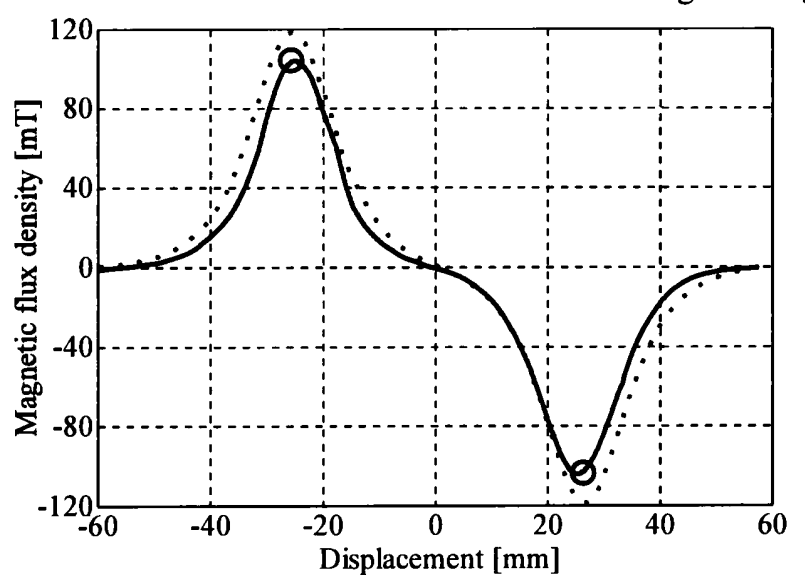

O Experimental, —Apporoximation, $\cdots$ ANSYS

Fig. 4 Relation between displacement and magnetic flux density 


$$
v(t)=a \omega \cos (\omega t)
$$

として表される，aは振幅である

磁束密度分布ではピークが 2 点存在するので磁束密度変化 $B(t)$ は 2 関数の合成で同定を行うと考える. 図 1 内 の磁束を切る部分をコイル(1), コイル(2)としておく. コイル(1), コイル(2)の磁束密度変化 $B(x)$ はロジステイックピ 一ク関数より

$$
B(x)=\sum_{i=2}^{n} \frac{4 B_{n} \exp \left(-\frac{x_{b n}(t)-x_{c n}}{w}\right)}{\left\{1+\exp \left(-\frac{x_{b n}(t)-x_{c n}}{w}\right)\right\}^{2}}
$$

と仮定する. $x_{c}$ はコイルの中心から磁石中心までの距離である. $x_{b}$ は磁束を切るそれぞれのコイルの中心 $\left(x_{0}= \pm 22\right.$ $\mathrm{mm}$ )を初期位置として代入したものであり $x_{b 1}, x_{b 2}$ は

$$
\begin{aligned}
& x_{b 1}(t)=-x_{0}-x(t) \\
& x_{b 2}(t)=x_{0}-x(t)
\end{aligned}
$$

となる. 図 2 における装置の中心 BB'間の磁束密度変化と理論の磁束密度変化を同定させたグラフを図 4 に示す. 図 4 からわかるように理論式は装置内の磁束密度変化と表現できる. 電圧 $V(t)$ は式(1) (6)より

$$
V(t)=a \omega L \cos (\omega t) \sum_{i=2}^{n} \frac{4 B_{n} \exp \left(-\frac{x_{b n}(t)-x_{c n}}{w}\right)}{\left\{1+\exp \left(-\frac{x_{b n}(t)-x_{c n}}{w}\right)\right\}^{2}}
$$

となる.このとき電圧值はコイル11, コイル(2)で正負が異なるが, 1 つのコイルとしてみた際には電流は同じ方向 となるので, 電圧値はコイル(1)とコイル(2)で発生した電圧の合計である.よって発電量 $P(t)$ は

$$
P(t)=\frac{V(t)^{2}}{R_{i n t}+R_{e x t}}
$$

となる.ここで $R_{i n t}$ はコイルによる内部抵抗, $R_{e x t}$ は外部抵抗である. オームの法則からコイルに流れる電流を $I(t)$ とすると

$$
I(t)=\frac{V(t)}{R_{\text {int }}+R_{\text {ext }}}
$$

となる.したがってよってコイルにかかる減衰力 $F$ はローレンツの式から

$$
F=B(x) I(t) L=\frac{\{B(x) L\}^{2}}{R_{\text {int }}+R_{\text {ext }}} v(t)
$$

となり, 減衰係数は

$$
c(x)=\frac{\{B(x) L\}^{2}}{R_{i n t}+R_{e x t}}
$$


として表される. 以上のことから本装置では减衰係数はコイルの位置 $x(t)$ に依存することがわかる.

\section{3. 発亘 - 抵抗力实全}

本装置の減衰力と発電量を前節で述べた理論値と比較するために強制振動実験を行った. 実験の概要図を図 5 に示す．本装置の片側は荷重計を介して地面に固定された柱に固定し, もう一方はロッドエンドを用いて振動台 に固定するように設置した. 発電と抵抗力を同時に測定してしまうと, 計器による外部抵抗が大きいために抵抗 カが下がってしまうので, 発電と抵抗力の測定は別々で行う. 電圧の測定時は周波数 $3.0 \mathrm{~Hz}$, 振幅 $10 \mathrm{~mm}$ で測定 した. 電磁誘導を起こしているコイルの電圧を測定し, 式(7)の理論と比較する. 減衰力の発生を確かめるために, 短絡回路々開放回路のコイルの抵抗が 0 とめの場合で行った. なお開放回路では摩擦力と慣性力で抵抗力が構成 され，短絡回路でも同様に摩擦力と慣性力がかかっている．抵抗力の測定についてはコイルを短絡回路または開 放回路に変えて, 周波数 $0.5 \sim 3.0 \mathrm{~Hz}$, 振幅 $10 \mathrm{~mm}$ で振動させた時の荷重と変位を測定し, 抵抗力特性を求めた.

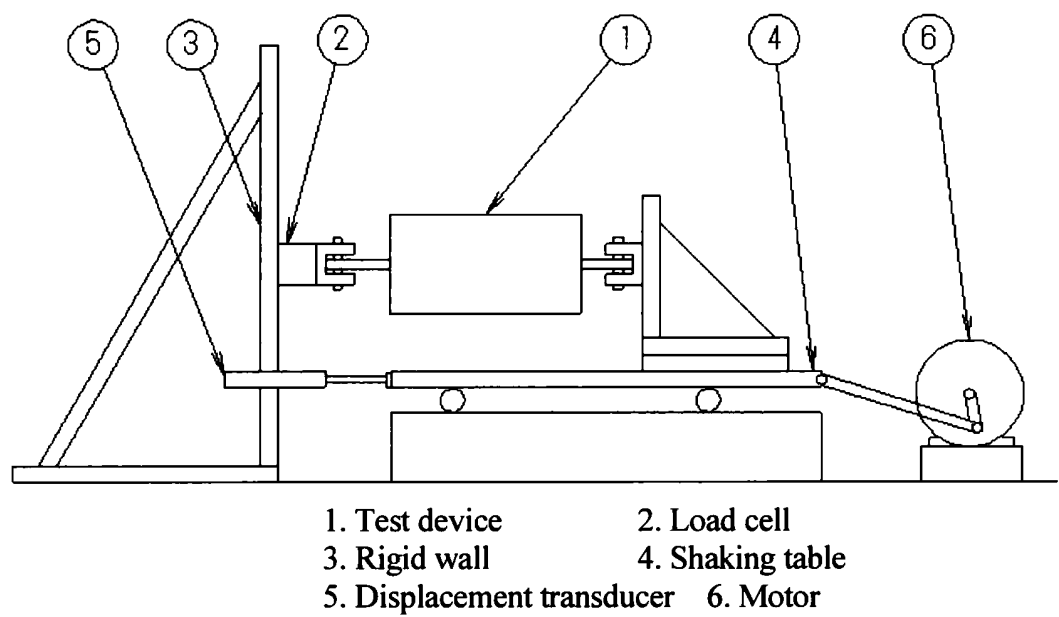

Fig. 5 Vibration test setup

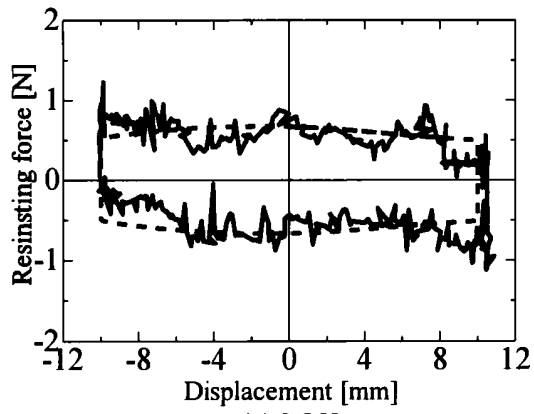

(a) $0.5 \mathrm{~Hz}$

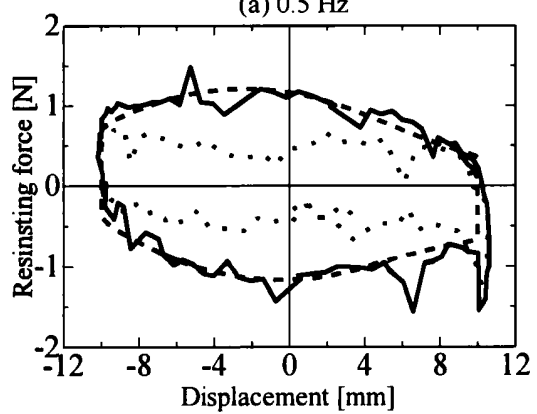

(d) $2.0 \mathrm{~Hz}$

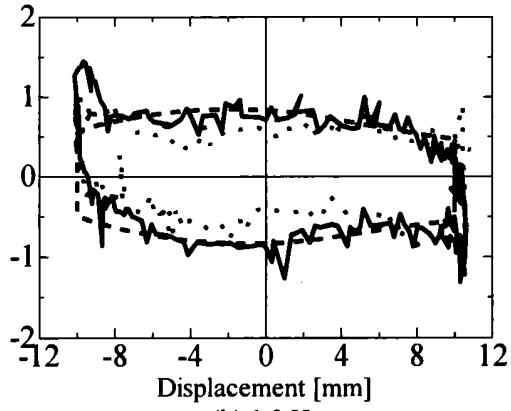

(b) $1.0 \mathrm{~Hz}$

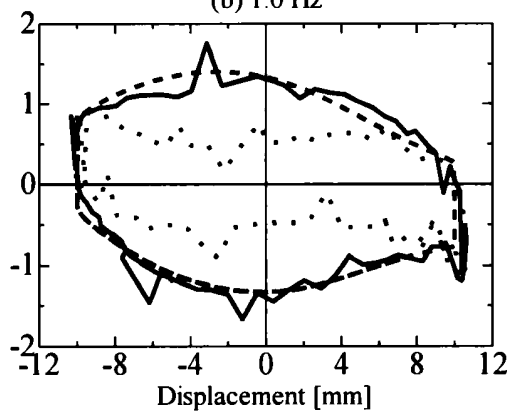

(e) $2.5 \mathrm{~Hz}$

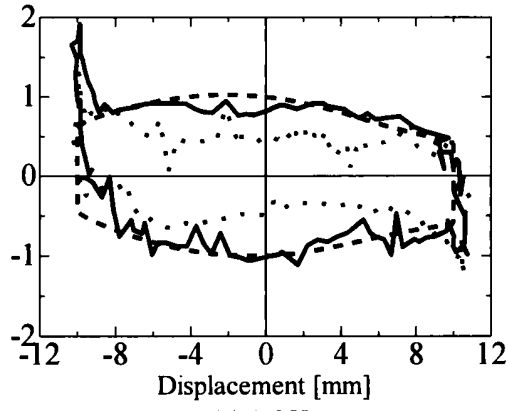

(c) $1.5 \mathrm{~Hz}$

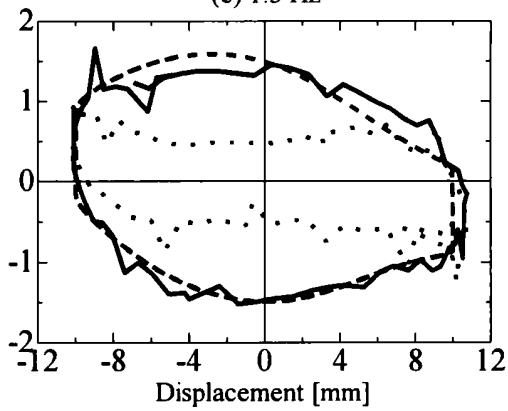

(f) $3.0 \mathrm{~Hz}$

-Short circuit Exp., --Short circuit Cal. ․Open circuit Exp.

Fig. 6 Resisting force characteristics 


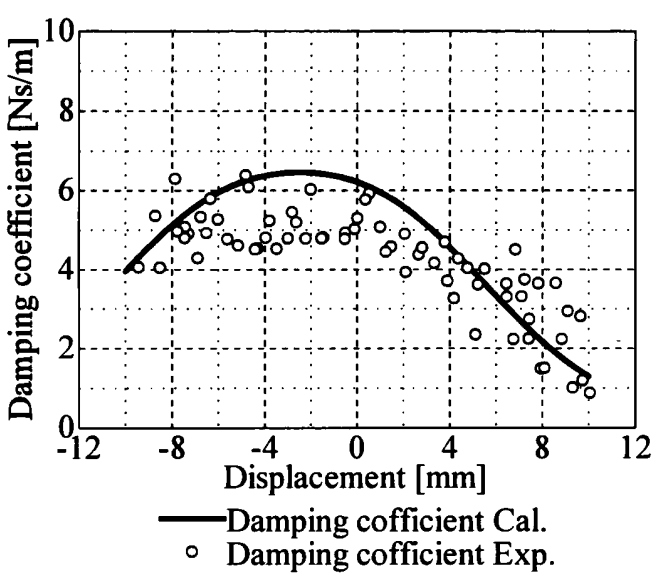

Fig. 7 Relation between displacement and damping coefficient

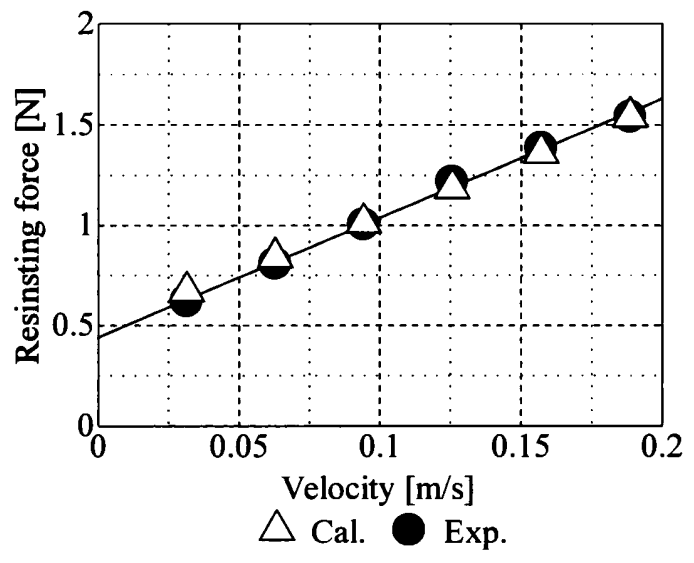

Fig. 8 Relation between velocity and resisting force

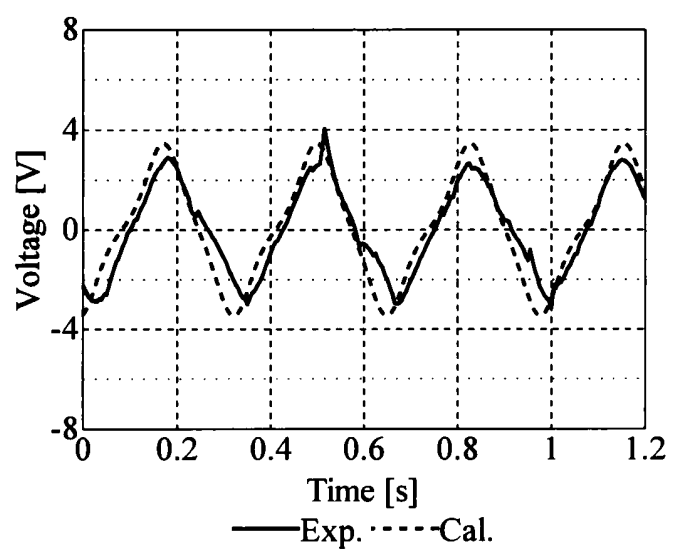

Fig. 9 Terminal voltage in case of short circuit

抵抗力実験の結果を式(10)から得られる理論值と合わせた抵抗力特性を図6に示す.実線が短絡回路の実測値, 破線が短絡回路の理論值, 点線が開放回路の実測值である.開放回路では振幅の端点で抵抗力が強く出ているが, これはリニアブッシュによる影響である. この抵抗力特性より摩擦力は $0.4 \mathrm{~N}$ として計測された. 短絡回路では 抵抗力特性はほぼ理論通りであるのがわかる. 短絡回路では速度が大きくなるにつれて減衰力も比例的に大きく なる. $3.0 \mathrm{~Hz}$ の時の減衰係数と変位の関係を図 7 に, 短絡時の抵抗力の最大值と速度の関係を図 8 に示す. 図 7 では抵抗力から摩擦力と慣性力を除いた值を速度で割ることで求めた. 図 7 より変位によって減衰係数は変化し ており，実測値も似たように変化した．図 8 ではリニアブッシュによる影響を除くために振幅が $0 \mathrm{~mm}$ 付近にお ける抵抗力の最大值として計算した. 図 8 から本装置の最大の減衰係数は $5.962 \mathrm{Ns} / \mathrm{m}$ として算出され, 式(11)を 用いて求めた理論值の减衰係数は $6.487 \mathrm{Ns} / \mathrm{m}$ となった.

発電実験から得られた波形に $10 \mathrm{~Hz}$ のローパスフィルターを介した值を用いて式(7)の理論式と同定させた結果 を図 9 に示す. 実線が実測值, 破線が理論值である. 図 9 より理論值と実測值で位相差が生じているのがわかる. これはコイルのインピーダンスによるものであるが，インピーダンスの位相差によって総発電量が変化するこの とはない. また位相差はあるが理論と実測の波形の傾向は一致した. 電圧ピーク値については, 理論が $3.8 \mathrm{~V}$, 実 測が約 $3.0 \mathrm{~V}$ 強となった. 理論と実測の電圧ピーク值のわずかな差は, コイル中心と装置の中心がずれておりコ イルが横切る磁束量がわずかに少ないのが原因と考えられる.

\section{4. 周波数店管实政}

試作した本装置の制振性能を調べるために標識柱に取り付けて，周波数応答実験を行った．実験に用いた標識 柱は全高 $7.5 \mathrm{~m}$ の $\mathrm{F}$ 型標識柱を $1 / 3$ スケールにしたもので, 実験モデル図を図 10 に, その諸元を表 2 に示す. 標 
識柱の固有値 $f$ は主系の質量を $m_{1}$ とすると

$$
f=\frac{1}{2 \pi} \sqrt{\frac{k}{m_{1}}}
$$

として求められる.この固有值に合わせ, 標識板の先端に試作した本装置を動吸振器として設計をする．標識 柱との質量比 $\mu$, 動吸振器の剛性 $k_{2}$, 减衰係数 $c_{2}$ は質量体の質量は

$$
\begin{aligned}
& \mathrm{m}=\frac{m_{2}}{m_{1}} \\
& k_{2}=\frac{k_{1} \mu}{(1+\mu)^{2}} \\
& c_{2}=2 \sqrt{m_{2} k_{2}} \sqrt{\frac{3 \mu}{8(1+\mu)^{3}}}
\end{aligned}
$$

となる.

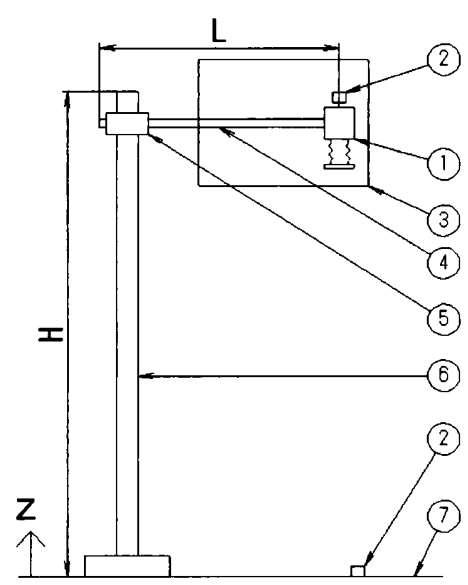

1. Dynamic absorber 2. Accelerometer

3. Sign board

4. Beam

Table 2 Specification of the test device

\begin{tabular}{|l|l|}
\hline Beam $L$ & $1130 \mathrm{~mm}$ \\
\hline Clamp $H$ & $2300 \mathrm{~mm}$ \\
\hline Neutral frequency $f$ & $3.57 \mathrm{~Hz}$ \\
\hline Pole Weight $m_{1}$ & $10.5 \mathrm{~kg}$ \\
\hline Pole Stiffness $k_{1}$ & $4.28 \times 10^{3} \mathrm{~N} / \mathrm{m}$ \\
\hline Ratio of mass $\mu$ & $0.76 \times 10^{-1}$ \\
\hline Device Weight $m_{2}$ & $0.80 \mathrm{~kg}$ \\
\hline Stiffness $k_{2}$ & $282 \mathrm{~N} / \mathrm{m}$ \\
\hline Damping coefficient $c_{2}$ & $5.69 \mathrm{Ns} / \mathrm{m}$ \\
\hline
\end{tabular}

5. Clamp

6. Pole

7. Shaking table

Fig. 10 Frequency response test setup

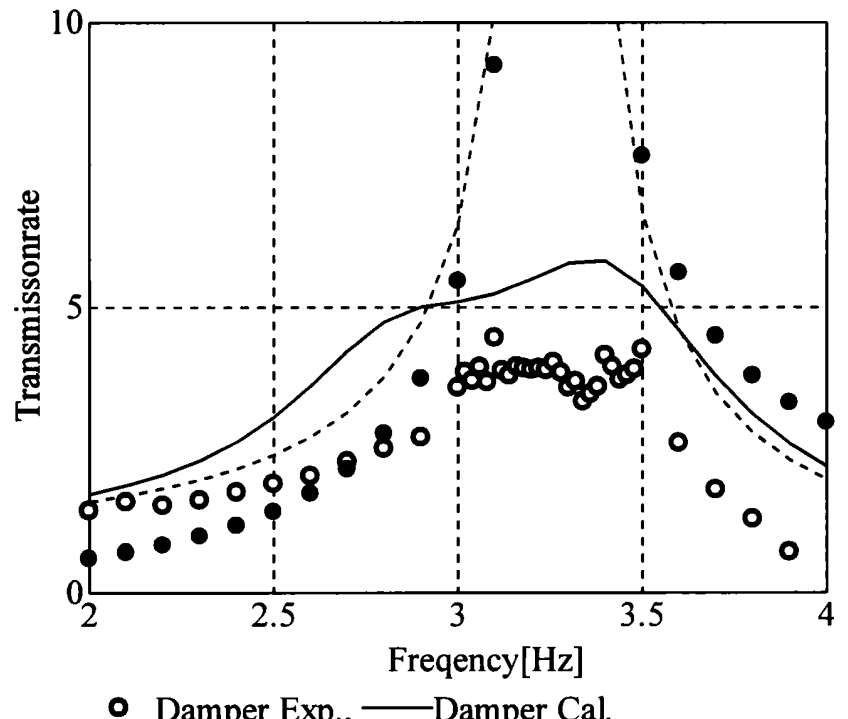

- Without dampeExp., :---Without damper Cal.

Fig. 11 Frequency responses 
加速度計を標識板先端と振動台に取り付けた．標識柱を上下方向に加振させ，標識板と振動台の加速度を積分 し，変位による応答倍率を算出した，取り付けた本装置を設置した場合としない場合で，応答倍率を算出し，理 論值を同定し比較考察を行った. 標識柱のみを摇らした場合と動吸振器を取り付けた場合を, 理論値と合わせて 図 10 に示す. 標識柱だけでは約 45 倍の応答があるが, 試作した動吸振器を取り付けたことで态答が約 4 倍にま で低减した，二つの山の高さが一致しないのは標識柱の構造减衰が原因である. また本装置は减衰係数が一定で はないために，質量体の振幅による減衰係数の変化の影響も原因である. しかし減衰係数が一定でなくても広帯 域で高い制振性能を持つことがわかる.

\section{5. 絬田}

発電式振動抑制装置を試作し, 磁束密度変化を非線形の関数として仮定し, 発電と減衰の理論式を求め, 発電・ 抵抗力実験，1/3 スケールの標識柱を用いた周波数応答実験を行い本装置の有用性について検証した. そのまと めについて以下に述べる.

(1) 試作した装置ではコイルが横切る磁束量が変化するため, 電磁誘導による電圧はコイルの初期位置に依存す る. 振幅，コイルの長さ，周波数，装置の中心磁束密度を増加させるとピーク電圧は増加する.

(2) 装置全体は RL 回路をなしており，コイルのインピーダンスによる位相差が生じる. しかし位相差が生じる だけで，総発電量には影響は生じない。

(3) 抵抗力は短絡回路において摩擦力, 慣性力, 減衰力で構成されている. 装置の中心磁束密度, コイルの長さ, コイルの速度を増加させると減衰力は増えるが，コイルを含めた全電気抵抗を大きくすると減衰力は減少す る. 抵抗が大きくなると発電量もまた減少する.

(4) 減衰俰数はコイルの位置によって変化する. そのためコイルの初期位置と装置の初期位置との中心にずれが 生じる場合, 減衰力も変化し，抵抗力の履歴曲線は楕円ではなく多少歪な形になる.

(5) 減衰係数が一定でない動吸振器を標識柱に取り付けた場合でも広帯域の周波数にて高い制振効果が得られ る.

\section{考文献}

（1）西村功，“非定常不規則外乱下における能動型動吸振器のエネルギー吸収応答”，日本建築学会構造系論文集， Vol. 69, No.575(2004), pp. 57-64.

（2）日野順市，稲井新，高木均，芳村敏夫，“形状記憶合金を用いた動吸振器に関する研究”，日本機械学会論文集 C 編, Vol. 71, No. 710(2005), pp. 2863-2869.

(3) Lei Z., Brian, S., Jurgen, S. and Yu, Z., "Design and characterization of an electromagnetic energy harvester for vehicle suspensions", Smart Materials and Structures, Vol.19, No. 4(2010), pp. 1-10.

(4) Yu, Y., Atsuo, S., Masanori, Y., Yasusi, S., Tetsuji, O., “Quenching of vortex-induced vibrations of towering structure and generation of electricity using Hula-Hoops", Journal of Sound and Vibration, Vol. 272, Issues 1-2(2004), pp21-38.

(5) 中野公彦, 黒瀬智広, 中山敦志, 斉藤俊, “歩行時に人体に発生する加速度の計測と携帯型発電機の発電量推定”, IIP 情報・知能・精密機器部門講演会講演論文集, Vol. 13, No.2(2002), pp 149-152 